\title{
Effect of Organic Waste Source on Methane Production during Thermophilic Digestion Process
}

\author{
Rafik M. Hesnawi and Ruqua A. Mohamed
}

\begin{abstract}
This work was conducted to determine the production of methane from different organic waste substrates. Laboratory-scale reactors $(5.0 \mathrm{~L})$ operated at $55^{\circ} \mathrm{C}$ was used. Three different types of organic wastes were used: residential food waste, chicken manure, and secondary sludge from wastewater treatment plant. After 90 days of thermophilic digestion, it was found that the methane content range from 57 to $97.05 \%$. The highest production of methane was obtained with municipal wastewater sludge while the lowest production was obtained with food waste. It was also found that methane production was affected by the ratio of waste to water $(w / v)$. Wastes dilution ratio of 1:2 showed comparatively higher methane content than the wastes dilution ratio of $1: 1$.
\end{abstract}

Index Terms-Methane production, organic waste, thermophilic digestion, wastewater sludge.

\section{INTRODUCTION}

Municipal solid waste management is one of the major environmental problems of the Libyan cities. Improper management of municipal solid waste (MSW) causes hazards to inhabitants. The generation rate per capita of solid waste in Libya is $(0.8 \mathrm{~kg} / \mathrm{day})$, it varies however, in cities and rural areas, the generation rate may be as high as (1.0kg /day) in big cities, whereas in small cities and rural areas it might be as low as $(0.6 \mathrm{~kg} /$ day $)$ per person [1]. In 2005 , the quantities of solid waste generated in Tripoli and Benghazi were estimated to be 750 tones per day and 1000 tones per day, respectively. Most of these quantities are collected by municipalities and common service councils and transferred to landfills throughout the city. Landfilling is considered to be the best method for Libya due to its low cost and the availability of land required. Municipal solid wastes in Libya contain $50-60 \%$ of food waste. This portion can be treated using anaerobic biological treatment to produce biogas such as methane. There are several research studies on anaerobic digestion of different organic wastes. One study [2] found that the food waste has potential for methane production ranging from 96 to $426 \mathrm{ml} \mathrm{dry} \mathrm{g}^{-1}$ depending on the type of food used. Other study also found that the methane yields of different food wastes at $37^{\circ} \mathrm{C}$ after 28 days of digestion were $482,294,277$ and $472 \mathrm{ml} / \mathrm{g}$ VS for cooked meat, boiled rice, fresh cabbage and mixed food wastes, respectively [3]. Other study [4] on food waste reported biogas yield being in the range of $661-796 \mathrm{ml} / \mathrm{g}$ VS with a methane content of 52-70\%. Anaerobic digestion of agricultural residues such as potato waste and sugar beet leaves gave gross energy yields of $2.1-3.4 \mathrm{~kW} \mathrm{~h} / \mathrm{kg} \mathrm{VS}$ in

Manuscript received January 15, 2013; revised March 14, 2013. com) the form of methane [4]. The gas obtained during anaerobic digestion comprises of $55-70 \%$ methane, $30-45 \%$ carbon dioxide, some inert gases and sulfur compounds and energy content of $\mathrm{CH}_{4}$ per ton MSW 167-373 MJ/Ton MSW. Usually $100-200 \mathrm{~m}^{3}$ of total gas are produced per ton of organic MSW digested [5]. However, there are a large number of factors that affect biogas production efficiency such as digester temperature, volatile solids input, and retention time. References [6], [7] compared the biogas production of the organic solid waste at mesophilic $\left(37^{\circ} \mathrm{C}\right)$ and thermophilic $\left(55{ }^{\circ} \mathrm{C}\right)$ conditions using a $3 \mathrm{~m}^{3}$ continuous stirred-tank reactor. The organic waste was separated from household MSW and contained TS and VS of $76 \%$ and $34 \%$, respectively. At the mesophilic condition the biogas yield achieved was $200 \mathrm{ml} / \mathrm{g}$ VS and VS reduction was $23 \%$, whereas at the thermophilic condition the biogas yield was $410 \mathrm{ml} / \mathrm{g}$ VS and $43 \%$ VS reduction. However, the authors of these studies observed that biogas productivity at thermophilic condition decreased to 290 $\mathrm{ml} / \mathrm{g}$ VS when the organic loading rate (OLR) was increased from 6.9 to $9.2 \mathrm{~g}$ VS/ L.d. Hydraulic retention time (HRT) also found to affect biogas productivity where [8], [9] found that the maximum biogas productivity with methane content of $70 \%$ was obtained at (HRT) of 24 days whereas at HRT of 12 day, methane content was $20 \%$. Others studied the effect of hydraulic retention time and organic loading on anaerobic digestion of poultry slaughterhouse wastes and found that anaerobic digestion appeared feasible with a loading of up to $0.8 \mathrm{~kg} \mathrm{VS} / \mathrm{m}^{3} \mathrm{~d}$ and an HRT of 50 -100 days [10]. On the other hand, higher OLR in the range from $1.0-2.1 \mathrm{~kg} \mathrm{VS} / \mathrm{m}^{3} \mathrm{~d}$, and shorter HRT in the range of 13-25 days, the process appeared inhibited and /or overloaded, as indicated by the accumulation of volatile fatty acids and the decline in the methane yield [11]. The above studies suggested that operating thermophilic temperature would be beneficial for biogas production but its content depends up organic waste type, volatile solid content and sludge retention time. Therefore, the main objective of this study was to investigate the effect of oragnic waste source on the performance of anaerobic digestion process.

\section{MATERIALS AND METHOD}

\section{A. Substrate Types}

Three different municipal solid wastes (MSW) were used as substrates:- (1) Food waste from residential waste (FW), (2) Chicken manure from poultry barns (CM) and (3) Secondary sludge from wastewater treatment plant (SWWTP). All wastes characteristics including total solids (TS), volatile solids (VS), pH, alkalinity, chemical oxygen 
demand (COD), and biological oxygen demand (BOD) were determined. All analyse were performed using the standard methods for examination of water and wastewater [12]. Initial characteristics of substrate types are shown in Table I.

TABLE I: INITIAL CHARACTERISTICS OF ORGANIC WASTE SUBSTRATES

\begin{tabular}{cccc}
\hline Parameters & FW & CM & SWWT \\
TS mg/g & 668.53 & 949 & 927.27 \\
VS mg/g & 586 & 866 & 842 \\
PH & 3.3 & 7.3 & 6.8 \\
Alkalinity g/l & 0.2 & 7.7 & 8.2 \\
COD mg/l & 980 & 950 & 1050 \\
BOD $_{5} \mathrm{mg} / 1$ & 630 & 570 & 720 \\
\hline
\end{tabular}

\section{B. Waste Preparation}

To determine the effect of operation parameters on the rate of biogas production, all wastes were diluted with distilled water to obtain various ratios of waste to water $(\mathrm{W} / \mathrm{V}),(1: 1,1: 2)$. After dilution the $\mathrm{pH}$ of the prepared slurry was adjusted to (6.5- 7.5) when necessary using $0.02 \mathrm{~N} \mathrm{NaOH}$ in order to achieve a high biological activity. Before digestion the slurries, their parameters were subjected to analysis (Table II) for TS, VS, pH, COD, $\mathrm{BOD}_{5}$ using the standard methods for examination of water and wastewater [12].

\section{Analytical Methods}

All analyses were performed by standard methods for examinations of water and wastewater [12]. Briefly, TS and VS analysis were according to method 2540-B described in APHA1998. Total solids (TS) content was determined after heating $\left(105 \mathrm{C}^{\circ}\right.$ for $\left.1 \mathrm{~h}\right)$, cooling, desiccating, and weighing until the weight change was less than $4 \%$. Volatile solids were determined by ignition of the residue produced in TS analysis to constant weight in a muffle furnace at a temperature of $550 \mathrm{C}^{\circ}$. The $\mathrm{pH}$ value was measured using a $\mathrm{pH}$ meter, type (JENWAY -3150). The Alkalinity was measured by titration with $0.05 \mathrm{M} \mathrm{H}_{2} \mathrm{SO}_{4}$. The COD was measured by the sealed tube method (sample size $=2 \mathrm{ml}$ ) (Hach, $1500 \mathrm{mg} / \mathrm{l} \mathrm{rang)} \mathrm{model} \mathrm{LANGE} \mathrm{-DR-2800,} \mathrm{and}$ $\mathrm{BOD}_{5}$ was measured using BOD-Sensor and Inductive Stirring System.

TABLE II: CHARACTERISTICS OF SOLID WASTE USED IN THE EXPERIMENT

\begin{tabular}{|cccccccc|}
\cline { 3 - 8 } \multicolumn{1}{c}{} & \multicolumn{3}{c}{ FW } & \multicolumn{3}{c|}{ Dilution Factors SWWT } & \multicolumn{2}{c|}{ CM } \\
\cline { 2 - 8 } Parameter & $1: 1$ & $1: 2$ & $1: 1$ & $1: 2$ & $1: 1$ & $1: 2$ \\
TS mg/g & 348 & 201 & 395 & 300 & 403 & 300 \\
VS mg/g & 202 & 120 & 313 & 218 & 200 & 150 \\
PH & 6.5 & 6.8 & 6.8 & 7.01 & 7.36 & 7.5 \\
BOD $_{5} \mathrm{mg} / 1$ & 510 & 410 & 480 & 375 & 450 & 220 \\
$\mathrm{COD}_{\mathrm{mg}}$ & 850 & 683 & 800 & 625 & 750 & 367 \\
\hline
\end{tabular}

\section{Experimental Reactor set-up}

The reactors used for this study were plastic bottles with a working volume of 5 litres. The reactors were equipped with one part at the top, for biogas line,which was connected to the calibrated measuring cylinders with water displacement arrangements to measure the volume of gas collected (Fig.1) and were operated at the thermophilic $\left(55^{\circ} \mathrm{C}\right)$ temperature. The reactors were placed in three separate water baths to achieve the desired temperature. Biogas production and methane content were measured every week during the period of the study.

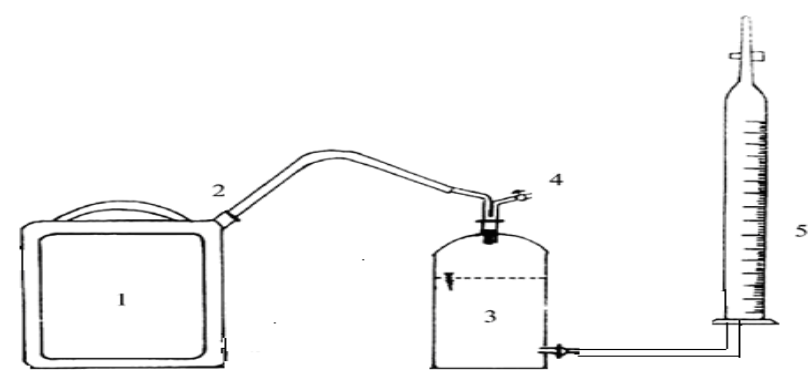

1-digester $(\mathrm{V}=5 \mathrm{~L})$, 2- Gas opening, 3- Water diplacement jar, 4- Gas outlet, 5- Measuring jar

Fig. 1. The experimental set-up.

Biogas was collected by using sampling gas bags (Urine Bags). It then was sampled by inserting gas syringe into the bag and volumetric composition of biogas was analyzed by using gas chromatography (CARLO ERBA STRUMENTAZIONE - GC6000 -VEGA.SERIES) equipped with flame ionization detector (FID) was used to analyze gas composition. The carrier gas used was Hydrogen $\left(\mathrm{H}_{2}\right)$ with flow rate of $30-40 \mathrm{ml} / \mathrm{min}$. The oven temperature was set at constant temperature of $50^{\circ} \mathrm{C}$. The column used was Silicon ( $\mathrm{Si}$ ). The volume of biogas was collected by liquid displacement system. The total volume of the biogas generated was measured, and the composition of the biogas was analyzed every week.

\section{RESULTS AND DISCUSSION}

Production of methane from anaerobic digestion process at $55 \mathrm{C}^{\circ}$ for different substrate types is presented in Fig. 2. The results showed that methane production rate varies in percentage according to the type of waste substrate used. The highest methane percentage $(97.05 \%)$ was obtained for SWWT, while the CM and FW substrates yielded methane rates of $87.13 \%$ and $57.39 \%$, respectively.

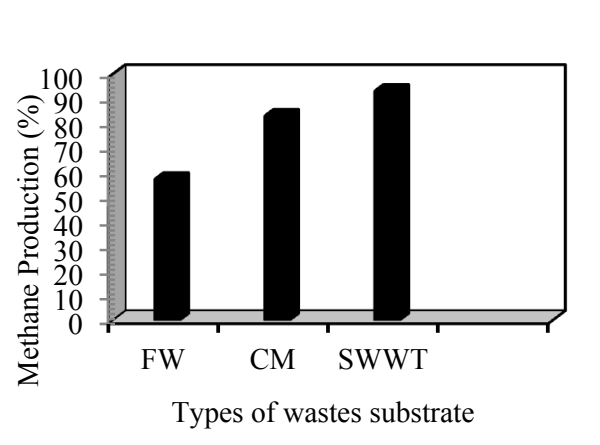

Fig. 2. Methane production from various organic wastes after 90 days

SRT has a remarkable effect on methane production rate (Fig. 3). When the SRT of waste increased inside the digester, methane production increased, and this indicates that the activity of methane producing bacteria increase gradually as time passes. The results also showed that the increasing rate varied depending on the type of waste. The difference in production rates started to be noticeable after the first 21 days where $53 \%$ of methane was produced with 
SWWT reactor while, for the same period, FW and CM reactors produced $28 \%$ and $35 \%$, respectively. This may be related to biodegradability of organic fraction of organic substrates. In this study, after 90 days of digestion, about $65 \%, 75 \%$ and $87 \% \mathrm{VS}$ conversion to biogas was achieved for FW, CM and SWWT, respectively (Fig. 4). The higher the VS removal, the higher methane production was achieved

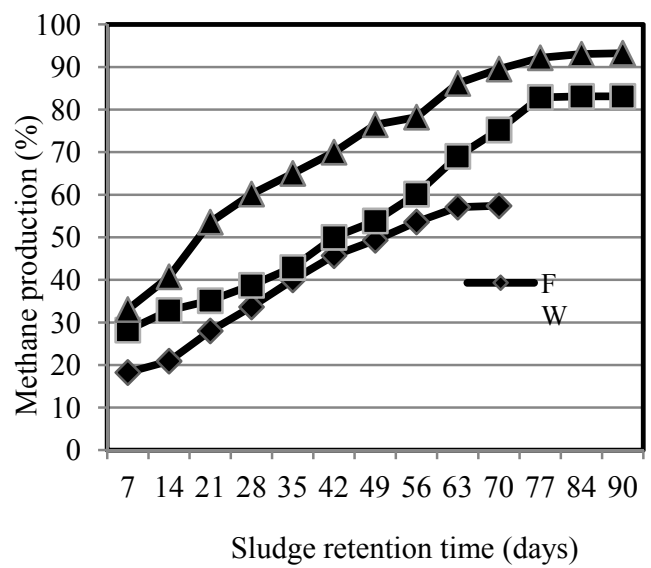

Fig. 3. Effect of SRT on $\mathrm{CH}_{4}$ production for various organic wastes at dilution factor of $1: 1$

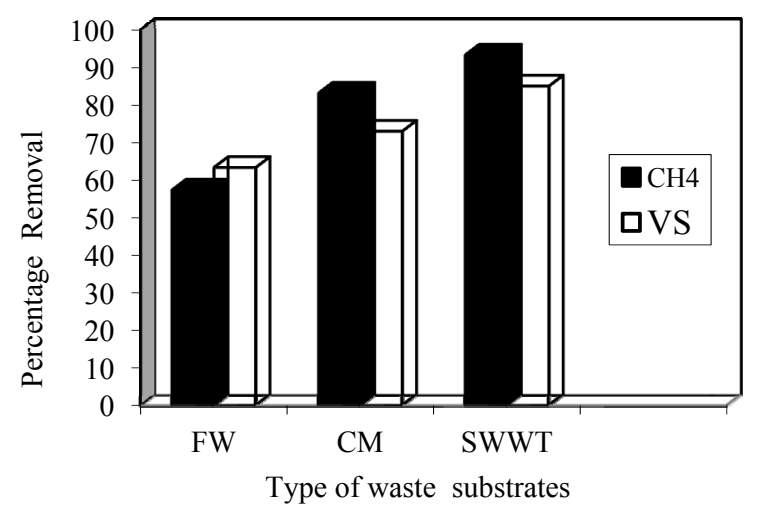

Fig. 4. The Relation between $\mathrm{CH}_{4}$ and VS removal percentages of different wastes after 90 days and at a dilution factor of 1:1

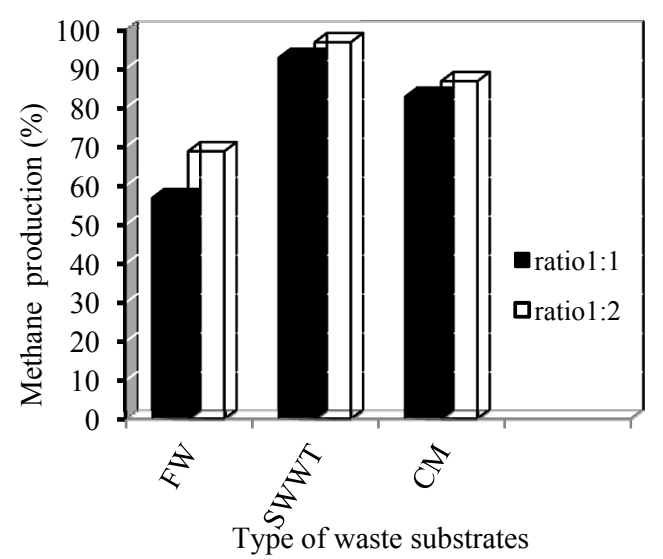

Fig. 5. Effect of dilution factor on $\mathrm{CH}_{4}$ production after 90 days of anaerobic digestion at $55^{\circ} \mathrm{C}$

The productivity of methane production was also affected by amount of water added to the reactor. The results in Fig. 5 showed that when the dilution factor increased the methane production increased by $11 \%$ for $\mathrm{FW}$ reactor substrates and 4 to $5 \%$ for both CM and SWWT. That can be attributed to the fact that water worked on forcing out the air from the digester before the start of production; and also to the fact that the waste characteristics can be altered by simple dilution where the concentration of certain constituents such as nitrogen and sulfur that produce products (ammonia and hydrogen sulfide) which are inhibitory to the anaerobic digestion process can be reduced.

\section{CONCLUSIONS}

The results of this study showed different behaviour patterns of methane production from organic wastes. The highest methane production $(97.05 \%)$ was obtained with SWWT reactor at sludge retention time of 77 days. It found also that the wastes dilution ratio of 1:2 showed comparatively higher methane content than the wastes dilution ratio $1: 1$.

\section{REFERENCES}

[1] S. Samer, "Benghazi city experiment for municipal solid wastes disposal," Environmental Periodic magazine, National Authority of Environment (in Arabic), pp. 13-16, 2005.

[2] A. Esa and R. Jukka, "Semi-continuous anaerobic digestion of solid poultry slaughterhouse waste: effect of hydraulic retention time and loading," J.Water Research, vol. 36, pp. 3175-3182, 2002.

[3] F. Boubaker and B. Ridha, "Thermophilic anaerobic co-digestion of olive mill wastewater with olive mill solid wastes in a tubular digester," Chemical Engineering Journal, vol. 132, pp. 195-203, 2007.

[4] A. Mata and L. Maces, "Anaerobic digestion of organic solid wastes: an overview of research achievements and perspectives," Bioresource Technology, vol. 74, pp. 3-16, 2000.

[5] W. Parawira, M. Read, and L. BjÖrnsson, "Energy production from agricultural residues: High methane yields in pilot-scale two-stage anaerobi digestion," Bioresource Technology, pp. 36-42, 2008.

[6] J. Cho and S. Park, "Biochemical methane potential and solid state anaerobic digestion of Korean foodwaste," Bioresource Technology, vol. 52, no. 3, pp. 245-253, 1995.

[7] F. Cecchi, A. Marcomini, P. Pavan, G. Fazz, and J. Mata-Alvarez, "Mesophilic digestion of organic fraction of refuse: performance and kinetic study," Waste Manag.Res., vol. 8, pp. 33-44, 1990.

[8] J. Lay, Y. Li, T. Noike, J. Endo, and S. Ishimoto, "Analysis of environmental factors affecting methane production from high-solids organic waste," Water Sci.Technol, vol. 36, pp. 493-500, 1996.

[9] H. Bouallagui, Y. Touhami, R. Cheikh, and M. Hamdi, "Bioreactor performance in anaerobic digestion of fruit and vegetable wastes," Process Biochemistry, vol. 40, pp. 989-995, 2005.

[10] P. Cecchi, J. Pavan, A. Mata, C. Bqssetti, and C. Cozzolino, "Anaerobic digestion of municipal solid waste: thermophilic versus mesophilic performance at high solid," Waste Manag.Res, vol. 9, pp. 305-315, 1991.

[11] N. Themelis. Anaerobic digestion of biodegradable organics in municipal solid waste. [Online] . Available: www.biogasworks.com .

[12] APHA, Standard Methods for the Examination of Water and wastewater, 18th ed. American Public Health Association, Washington, DC, USA, 1998.

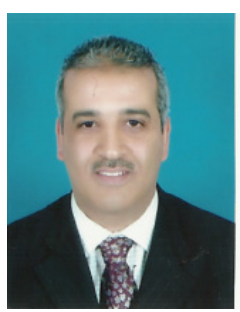

Rafik M. Hesnawi has Ph.D. in civil engineering from University of Manitoba, Winnipeg, Canada. His major field of study is in environmental engineering. He has earned his Ph.D. degree in 2004.

He is now working as Full Faculty Staff in the department of environmental science at university of Al-Zaytoona in Libya. He also acted as the Head of environmental research group at biotechnology research centre in Libya and the Head of environmental science and engineering department at the Libyan academy of post-graduate study.

Dr. Hesnawi is a member of scientific committee at biotechnology Research Centre-Libya and also a member of microbiology association of Tripoli. 